\title{
Campo Grande stylo and elephant grass mixed silages treated with microbial inoculant
}

\section{Silagens mistas de estilosantes Campo Grande e capim-elefante tratadas com inoculante microbiano}

\author{
Karina Guimarães Ribeiro ${ }^{1 *}$; Igor Alexandre de Souza²; João Paulo Sampaio \\ Rigueira $^{3}$; Andréia Santos Cezário ${ }^{4}$; Sebastião de Campos Valadares Filho'; \\ Odilon Gomes Pereira ${ }^{1}$
}

\section{Highlights:}

Stylo silage presents better chemical composition than elephant grass silage.

Stylo silage has less effluent and more fungi population than elephant grass silage.

Microbial inoculant reduces only butyric acid in mixed silages.

Uninoculated stylo silage with up to $75 \%$ of elephant grass is recommended.

\begin{abstract}
Tropical grass has some advantages for ensilage, such as high annual production of dry matter per unit area, perennity, low loss risk, and higher harvest flexibility. We aimed with this study to assess the chemical composition, microbial population, fermentation characteristics, and effluent production of stylo (Stylosanthes capitata $\times$ S. macrocephala cv. Campo Grande) silages with increasing proportions $(0,25,50,75$, and $100 \%)$ of elephant grass (Pennisetum purpureum Schum. cv. Cameroon), with or without microbial inoculant. We used a $5 \times 2$ factorial scheme in a completely randomized design, with three replicates. There was an effect of interaction between proportions of elephant grass and microbial inoculant on yeast population, butyric acid and ammonia-nitrogen content, and effluent loss. The proportions of elephant grass affected the chemical composition, lactic acid bacteria and mold populations, $\mathrm{pH}$, and lactic and propionic acid contents. Dry matter, acid detergent insoluble nitrogen, and lactic acid contents and the $\mathrm{pH}$ values were negatively affected by microbial inoculant. We conclude that stylo provides silage with better chemical composition and lower effluent production, although with a higher mold and yeast population, than elephant grass. The microbial inoculant does not improve the chemical and fermentative characteristics of silages, except for the reduction of butyric acid. We recommend uninoculated stylo silage with up to $75 \%$ of elephant grass.
\end{abstract}

Key words: Chemical composition. Effluent production. Fermentation characteristics. Microbial population.

${ }^{1}$ Profs. Drs., Universidade Federal de Viçosa, UFV, Viçosa, MG, Brasil. E-mail: karina_ufv@yahoo.com.br, scvfilho@ufv.br, odilon@ufv.br

2 Técnico em Laboratório, Dr., Universidade Federal dos Vales do Jequitinhonha e Mucuri, UFVJM, Unaí, Minas Gerais, Brasil. E-mail: igordadim@hotmail.com

3 Prof. Dr., Universidade Estadual de Montes Claros, UNIMONTES, Janaúba, MG, Brasil. E-mail: joao.rigueira@unimontes.br

${ }^{4}$ Prof $^{\mathrm{a}} \mathrm{Dr}^{\mathrm{a}}$, Instituto Federal Goiano, IFG, Morrinhos, GO, Brasil. E-mail: andreia.cezario@ifgoiano.edu.br

* Author for correspondence 


\section{Resumo}

As gramíneas de clima tropical apresentam algumas vantagens para ensilagem, como alta produtividade anual de massa seca por unidade de área, perenidade, baixo risco de perda e maior flexibilidade de colheita. Objetivou-se avaliar a composição química, a população microbiana, as características fermentativas e a produção de efluente de silagens de estilosantes (Stylosanthes capitata x S. macrocephala cv. Campo Grande) com proporções crescentes $(0 ; 25 ; 50 ; 75 ;$ e 100\%) de capim-elefante (Pennisetum purpureum Schum. cv. Cameroon), com e sem inoculante microbiano. Utilizou-se o esquema fatorial $5 \times 2$, no delineamento inteiramente casualizado, com três repetições repetidas. Houve efeito da interação de proporções de capim-elefante e inoculante microbiano para população de leveduras, teor de ácido butírico e nitrogênio amoniacal em relação ao nitrogênio total e perda de efluente. As proporções de capim-elefante afetaram a composição química, as populações de bactérias do ácido láctico e mofos, o pH e os teores de ácido lático e ácido propiônico. O inoculante microbiano afetou negativamente os teores de matéria seca, nitrogênio insolúvel em ácido detergente, ácido láctico e o $\mathrm{pH}$. Conclui-se que o estilosantes proporciona silagem de melhor composição química e mais baixa produção de efluente, embora com mais alta população de mofos e leveduras que o capim-elefante. $\mathrm{O}$ inoculante microbiano não melhora as características químicas e fermentativas das silagens, exceto por reduzir ácido butírico. Recomenda-se silagem de estilosantes com até $75 \%$ de capim-elefante, não tratada com inoculante microbiano.

Palavras-chave: Características de fermentação. Composição química. População microbiana. Produção de efluente.

\section{Introduction}

Production of high-quality silage is dependent on management factors such as forage species, stage of maturity, moisture concentration at harvest, harvesting and ensiling methods, type of storage structure, and use of silage additives (Mahanna \& Chase, 2003). Among tropical grasses, elephant grass (Pennisetum purpureum Schum.) is one of the most used species in Brazil due to the ease of cultivation, good acceptability by animals, and high dry matter production. However, according to McDonald, Henderson and Heron (1991), perennial grasses also exhibit unfavourable characteristics, such as low water-soluble carbohydrate content, low dry matter content at harvest, high buffering capacity, low epiphytic population, and low energy content compared with corn or sorghum.

Stylosanthes cv. Campo Grande (a physical mixture of $80 \%$ Stylosanthes capitata and $20 \%$ Stylosanthes macrocephala) is the main legume currently used under grazing in the savannas of Brazil. Since its release in 2000, its use has increased due to its superior performance and development of the technology in close association with seed producers and farmers (Fernandes, Grof, Chakraborty, \& Verzignassi, 2005).

The fermentation process is more complicated in legumes compared with grasses, because legumes have a relatively low concentration of water-soluble carbohydrates and a high buffering capacity after harvesting (McDonald et al., 1991; Yahaya et al., 2004). However, promising results have been observed with Stylosanthes cv. Campo Grande silage, regarding the fermentation characteristics, intake, and performance of ruminant animals (Liu, Zhang, Shi, \& Sun, 2011; Souza, Pereira, Ribeiro, Santos, \& Valadares, 2014; Silva et al., 2015). The various products generated by microorganisms during silage fermentation can alter the nutritional aspects of forage. Therefore, high-quality silage should be void of undesirable compounds that could negatively affect animal performance, the environment, or net farm income (Kung Jr, Shaver, Grant, \& Schimidt, 2018). In this context, commercial microbial inoculants for silage are being used with very interesting results 
as regards the inhibition of the growth of aerobic and undesirable anaerobic microorganisms, and addition of beneficial microorganisms to improve fermentation and recovery of the forage dry matter (McDonald et al., 1991; Oliveira et al., 2017; Silva et al., 2018).

The objective with this study was to evaluate the chemical composition, microbial population, fermentation characteristics, and effluent production of stylo silage with increasing proportions of elephant grass $(0,25,50,75$, and $100 \%)$, with and without microbial inoculant.

\section{Material and Methods}

\section{Silage material and treatments}

The experiment was conducted at the Department of Animal Science of Federal University of Viçosa, UFV, Minas Gerais State, Brazil (2045'20" South latitude, $42^{\circ} 52^{\prime} 40^{\prime \prime}$ West longitude, and altitude of $650 \mathrm{~m}$ over sea level). The climate is humid and subtropical (Cwa, according to Koppen's classification). The average annual rainfall, collected in 20 years, is $1,431 \mathrm{~mm}, 85 \%$ of which occurs between October and March. The mean maximum and minimum temperatures are 26.1 and $14.0^{\circ} \mathrm{C}$, respectively.

A field of stylo and another of elephant grass were established apart from each other in an area of 0.2 ha, being harvested in January, rainy season in the central part of Brazil. Stylo was at the preflowering stage, and elephant grass was at the late vegetative stage, exactly 60 days of regrowth. The harvest was performed using a JF Z10 forage harvester (JF Agricultural Machinery, SP, Brazil); before ensiling, both forages were chopped, at the particle size of $2 \mathrm{~cm}$, using a harvesting platform model FAHARA-100 (Harama Q, Hinterland, RS, Brazil).

The forages were mixed in increased proportions of $0,25,50,75$, and $100 \%$ of elephant grass (Table 1). A microbial inoculant was applied to half of the treatments, determining the treatments with (I) and without (NI) microbial inoculation. The microbial inoculant was diluted in $2 \mathrm{~L}$ of deionized water at the rate of $5.0 \mathrm{~g}$ of inoculant per ton of fresh forage and then applied uniformly by a sprayer onto the forage that was uniformly mixed by a shovel. The same quantity of water was applied to the untreated material. The microbial inoculant has the base composition of Lactobacillus Plantarum, Pediococcus acidilactici, Lactobacillus salivarius subsp. salivarius (min. $1.89 \times 10^{10}$ colony-forming units $(\mathrm{CFU}) / \mathrm{g}$ ), and Enterococcus faecium (min. $2.10 \times 10^{9} \mathrm{CFU} \mathrm{g}$ ); enzymes (xylanase (min. 16 $\mathrm{U} / \mathrm{g}$ ), amylase (min. $200 \mathrm{UI} / \mathrm{g}$ ), cellulase (min. 10 $\mathrm{UI} / \mathrm{g}$ ), and hemicellulotytic enzyme (min. $16 \mathrm{U} / \mathrm{g}$ )); silicon dioxide; and saccharose (Sil-All ${ }^{\circledR} 4 \times 4$ from Alltech in Brazil).

\section{Table 1}

Chemical composition and microorganism population before ensilage of stylo cv. Campo Grande with increasing proportions of elephant grass cv. Cameroon

\begin{tabular}{lccccc}
\hline \multirow{2}{*}{ Variable } & \multicolumn{5}{c}{ Proportion of elephant grass (\%) } \\
\cline { 2 - 5 } & 0 & 25 & 50 & 75 & 100 \\
\hline $\mathrm{DM}\left(\mathrm{g} \mathrm{kg}^{-1}\right)$ & 221 & 208 & 206 & 195 & 178 \\
$\mathrm{CP}\left(\mathrm{g} \mathrm{kg}^{-1} \mathrm{DM}\right)$ & 137 & 122 & 113 & 104 & 90 \\
$\mathrm{NDF}\left(\mathrm{g} \mathrm{kg}^{-1} \mathrm{DM}\right)$ & 592 & 660 & 678 & 698 & 751 \\
$\mathrm{ADF}\left(\mathrm{g} \mathrm{kg}^{-1} \mathrm{DM}\right)$ & 432 & 474 & 452 & 444 & 448 \\
$\mathrm{ADIN}\left(\mathrm{g} \mathrm{kg}^{-1} \mathrm{DM}\right)$ & 271 & 269 & 188 & 151 & 154 \\
& & & & & continue
\end{tabular}


continuation

\begin{tabular}{llllll} 
LAB $\left(\log\right.$ cfu g $\left.^{-1} \mathrm{FM}\right)$ & 5.25 & NA & NA & NA & 5.48 \\
ENT $\left(\log\right.$ cfu g g $^{-1}$ FM & 7.19 & NA & NA & NA & 5.93 \\
MOLD $\left(\log\right.$ cfu g $\left.^{-1} \mathrm{FM}\right)$ & 5.00 & NA & NA & NA & 5.54 \\
YEAST $(\log$ cfu g-1 FM) & 6.13 & NA & NA & NA & 5.39 \\
\hline
\end{tabular}

DM - dry matter; CP - crude protein; NDF - neutral detergent fiber; ADF - acid detergent fiber; ADIN - acid detergent insoluble nitrogen; LAB - lactic acid bacteria; ENT - Enterobacteria; NA - not assessed.

Shortly after applying the treatments, the forages were ensiled at a density of $650 \mathrm{~kg} \mathrm{~m}^{-3}$ of fresh forage, using 20-L buckets equipped with snap caps fitted with Bunsen valves to allow the escape of gases. To capture the effluent, a cotton bag filled with sand weighing $4 \mathrm{~kg}$ was placed at the bottom of the buckets. The experimental silos were stored at room temperature $\left(25 \pm 1^{\circ} \mathrm{C}\right)$ and were opened 84 days after closing. The contents of each silo were mixed thoroughly, and sub-samples of $400 \mathrm{~g}$ of each treatment were collected to determine dry matter (DM), chemical composition, microbial population, and fermentation characteristics. Effluent production was calculated according to Jobim, Nussio, Reis and Schmidt (2007).

\section{Chemical composition analyses}

To determine the DM, samples were dried in a forced-air drying oven to a constant weight at 55 ${ }^{\circ} \mathrm{C}$, then ground through a $1-\mathrm{mm}$ screen in a Wiley mill (Wiley, model 4, Philadelphia, PA, USA), and an aliquot was used to determine the contents of crude protein (CP); neutral detergent fiber (NDF); acid detergent fiber (ADF) and lignin according to Detmann et al. (2012); acid detergent insoluble nitrogen (ADIN), according to Licitra, Hernandez and Van Soest (1996); and $\mathrm{NH}_{3}-\mathrm{TN}$ (ammonia nitrogen as part of the total nitrogen), according to Bolsen et al. (1992). Fresh silage samples (25 g) were homogenized in $225 \mathrm{~mL}$ sterile solution for 1 min using an industrial blender, and then the $\mathrm{pH}$ of this mixture was immediately measured using a $\mathrm{pH}$ meter.

\section{Microorganisms population}

Microbial groups were counted by using $25 \mathrm{~g}$ of fresh silage sampled from each silo; at each sample, $225 \mathrm{~mL}$ of phosphate buffer solution was added to obtain a dilution of $10^{-1}$ (Kung, 1996). Several dilutions were performed aiming to obtain dilutions varying from $10^{-1}$ to $10^{-7}$, and immediately plated in duplicate on sterile Petri dishes. Lactic acid bacteria (LAB) were determined on De Man-Rogosa-Sharpe (MRS) agar (Oxoid) after incubation at $32{ }^{\circ} \mathrm{C}$ for $48 \mathrm{~h}$. Enterobacteria was determined on Violet Red Bile Glucose Agar (VRBGA; Oxoid) incubated at $37^{\circ} \mathrm{C}$ for $24 \mathrm{~h}$. Yeasts and mold were determined on malt extract agar (Oxoid) after incubation at $32{ }^{\circ} \mathrm{C}$ for $48 \mathrm{~h}$. Only dishes with between 30 and $300 \mathrm{CFU}$ were counted. The results were transformed into log $\mathrm{x}$ to achieve normal distribution.

Organic acids were determined from the aqueous extract of silages using the methodology described by Kung (1996). This method consists in an aliquot of $25 \mathrm{~g}$ fresh silage mixed in $225 \mathrm{~mL}$ deionized water for $1 \mathrm{~min}$, then filtered on a filter paper, acidified with $50 \%$ sulfuric acid, and centrifuged for $15 \mathrm{~min}$ at $10,000 \mathrm{rpm}$. Lactic acid (LA), propionic acid (PA), and butyric acid (BA) were determined using a high-performance liquid chromatography (HPLC) of Shimadzu-BIORAD brand, SPD-10 model, C18 column, and reverse phase at a wavelength of $210 \mathrm{~nm}$.

\section{Statistical analysis}

Analyses of variance for the data were performed using a completely randomized design in a 5 
(proportions) $\times 2$ (inoculant) factorial arrangement with three replicates, totalizing 30 experimental units. If a significant effect at a level of $5 \%$ by the $F$ test was detected for the qualitative (inoculant) factor, a means test was not necessary, since this factor had two levels. However, if a significant effect was detected for the quantitative (proportion) factor, a regression analysis was applied to test the best model (linear or quadratic) that would adjust to the data. Data were analyzed using the SAEG software (Sistema para Análises Estatísticas [SAEG], 2007).

\section{Results}

\section{Chemical composition}

There was no significant effect $(P>0.05)$ of the interaction between proportions of elephant grass and microbial inoculant for all chemical variables evaluated, but a simple effect $(P<0.001)$ of proportions of elephant grass for all of them was detected. Regarding the microbial inoculant, significant effect for DM $(P<0.001)$, ADF $(P<$ $0.10)$, and ADIN $(P<0.10)$ contents was detected. The use of microbial inoculant reduced the ADF content in relation to the uninoculated silage. However, in general, there were no positive results (Table 2).

Table 2

Chemical composition, microorganism population, fermentation characteristics, and effluent loss in stylo cv. Campo Grande silages with increasing proportions of elephant grass cv. Cameroon, without and with microbial inoculant

\begin{tabular}{|c|c|c|c|c|c|c|c|c|c|c|c|c|c|}
\hline & \multicolumn{6}{|c|}{ Proportion of elephant grass (\%) } & \multicolumn{2}{|c|}{ Inoculant } & \multicolumn{5}{|c|}{ Level of significance $^{1}$} \\
\hline & 0 & 25 & 50 & 75 & 100 & SEM & Without & With & $\mathrm{P}$ & $\mathrm{I}$ & $\mathrm{P} \times \mathrm{I}$ & $\mathrm{L}$ & Q \\
\hline \multicolumn{14}{|c|}{ Chemical composition $\left(\mathrm{g} \mathrm{kg}^{-1}\right)$} \\
\hline $\mathrm{DM}$ & 234 & 227 & 213 & 203 & 211 & 1.1 & 219 & 216 & $* * *$ & $* * *$ & NS & $*$ & NS \\
\hline $\mathrm{CP}$ & 135 & 125 & 110 & 91 & 86 & 2.4 & 109 & 110 & $* * *$ & NS & NS & $* * *$ & NS \\
\hline $\mathrm{NDF}$ & 587 & 629 & 671 & 710 & 740 & 6.3 & 667 & 668 & $* * *$ & NS & NS & $* * *$ & NS \\
\hline $\mathrm{ADF}$ & 427 & 432 & 468 & 466 & 463 & 5.8 & 456 & 447 & $* * *$ & $*$ & NS & $*$ & NS \\
\hline ADIN & 215 & 172 & 166 & 163 & 101 & 7.1 & 156 & 171 & $* * *$ & $*$ & NS & $*$ & NS \\
\hline \multicolumn{14}{|c|}{ Microorganism population $\left(\log \mathrm{CFU} \mathrm{g}^{-1}\right)$} \\
\hline LAB & 7.36 & 7.82 & 8.03 & 8.14 & 6.60 & 0.19 & 7.5 & 7.7 & $* * *$ & NS & NS & NS & $* * *$ \\
\hline Mold & 4.41 & 4.26 & 3.77 & 3.46 & 2.10 & 0.21 & 3.2 & 3.7 & $* * *$ & NS & NS & $* * *$ & NS \\
\hline Yeasts & 0.82 & 0.92 & 0.51 & 0.33 & NS & 0.08 & - & - & $* * *$ & NS & $* * *$ & & \\
\hline \multicolumn{14}{|c|}{ Fermentation characteristics } \\
\hline $\mathrm{NH}_{3} / \mathrm{N}$ & 117.5 & 87 & 128 & 70 & 87.5 & 14.8 & - & - & $* * *$ & NS & $* * *$ & & \\
\hline $\mathrm{pH}$ & 4.74 & 4.58 & 4.67 & 4.85 & 3.76 & 0.03 & 4.4 & 4.5 & $* * *$ & $* * *$ & NS & NS & $* *$ \\
\hline $\mathrm{LA}\left(\mathrm{g} \mathrm{kg}^{-1}\right)$ & 35.8 & 30.2 & 39.2 & 32.5 & 87.8 & 5.2 & 51.0 & 39.0 & $* * *$ & $*$ & NS & NS & $* *$ \\
\hline $\mathrm{PA}\left(\mathrm{g} \mathrm{kg}^{-1}\right)$ & 9.0 & 14.0 & 15.8 & 11.6 & 10.5 & 1.3 & 12.0 & 12.0 & $*$ & NS & NS & NS & $*$ \\
\hline $\mathrm{BA}\left(\mathrm{g} \mathrm{kg}^{-1}\right)$ & 1.8 & 1.7 & 2.6 & 1.85 & 1.7 & 0.3 & - & - & NS & $* * *$ & $*$ & & \\
\hline Effluent $\left(\mathrm{kg} \mathrm{t}^{-1}\right)$ & 6.15 & 9.0 & 12.6 & 21.9 & 74.7 & 1.19 & - & - & $* * *$ & $* * *$ & $* * *$ & & \\
\hline
\end{tabular}

DM - dry matter; CP - crude protein; NDF - neutral detergent fiber; ADF - acid detergent fiber; ADIN - acid detergent insoluble nitrogen; $\mathrm{NH}_{3} / \mathrm{TN}$ - ammonia nitrogen related to total $\mathrm{N}$; LAB - lactic acid bacteria; LA - lactic acid; PA - propionic acid; BA - butyric acid; SEM - standard error of the mean; NS - not significant; L and Q - linear and quadratic effect for elephant grass proportions, respectively.

${ }^{1} \mathrm{P}=$ elephant grass proportions, $\mathrm{I}=$ microbial inoculant; $\mathrm{P} \times \mathrm{I}=$ interaction between elephant grass proportion and microbial inoculant.

$* * * 1 \%$; * 5\%; and * $10 \%$. 
As the proportions of elephant grass in silages increased, the contents of DM (231 to $203 \mathrm{~g} \mathrm{~kg}^{-1}$ ), CP (136 to $83 \mathrm{~g} \mathrm{~kg}^{-1}$ ), and ADIN (210 to $116 \mathrm{~g} \mathrm{~kg}^{-}$
1) linearly decreased and the NDF (745 to $590 \mathrm{~g}$ $\mathrm{kg}^{-1}$ ) and $\mathrm{ADF}$ (472 to $430 \mathrm{~g} \mathrm{~kg}^{-1}$ ) contents linearly increased (Table 3).

Table 3

Regression equations for variables fitted as a function of elephant grass cv. Cameroon proportions $(0,25,50,75$, and $\mathbf{1 0 0 \%}$ ) in stylo cv. Campo Grande silages (averages between without and with microbial inoculant)

\begin{tabular}{lcc}
\hline & Regression equations & $\mathrm{r}^{2} / \mathrm{R}^{2}$ \\
\hline Chemical composition $\left(\mathrm{g} \mathrm{kg}^{-1}\right)$ & & \\
\hline DM & $\mathrm{Y}=231.533-0.280185 \mathrm{X}$ & 0.78 \\
$\mathrm{CP}$ & $\mathrm{Y}=135.869-0.525492 \mathrm{X}$ & 0.98 \\
NDF & $\mathrm{Y}=590.268+1.54645 \mathrm{X}$ & 1.00 \\
ADF & $\mathrm{Y}=430.215+0.420706 \mathrm{X}$ & 0.70 \\
ADIN & $\mathrm{Y}=210.914-0.953257 \mathrm{X}$ & 0.85 \\
\hline Microorganism population $\left(\log \mathrm{CFU} \mathrm{g}^{-1}\right)$ & & 0.85 \\
\hline LAB & $\mathrm{Y}=7.24883+0.041908 \mathrm{X}-0.000467448 \mathrm{X}^{2}$ & 0.85 \\
Mold & $\mathrm{Y}=4.66688-0.0210535 \mathrm{X}$ & 0.70 \\
\hline Fermentation characteristics & & 0.84 \\
\hline pH & $\mathrm{Y}=4.4609+0.0184343 \mathrm{X}-0.000238476 \mathrm{X}^{2}$ & 0.79 \\
LA $\left(\mathrm{g} \mathrm{kg}^{-1}\right)$ & $\mathrm{Y}=36.8573-0.741787 \mathrm{X}+0.011872 \mathrm{X}^{2}$ & \\
PA $\left(\mathrm{g} \mathrm{kg}^{-1}\right)$ & $\mathrm{Y}=9.19406+0.238339 \mathrm{X}-0.0023393 \mathrm{X}^{2}$ & \\
\hline
\end{tabular}

DM - dry matter; CP - crude protein; NDF - neutral detergent fiber; ADF - acid detergent fiber; ADIN - acid detergent insoluble nitrogen; LAB - lactic acid bacteria; LA - lactic acid; PA - propionic acid.

\section{Microorganism population}

There was no significant effect $(P>0.05)$ of the interaction between proportions of elephant grass and microbial inoculant for LAB and mold populations; however, there was a significant effect $(P<0.001)$ for yeasts. There was a simple effect $(P<0.01)$ of the proportions of elephant grass for LAB and mold populations, while there was no significant effect of the microbial inoculant for the variables $(P>0.05$; (Table 2$)$.

The addition of elephant grass in the silages provided a quadratic response for $\mathrm{LAB}$ population. The maximum LAB population of $8.19 \log \mathrm{CFU} \mathrm{g}^{-1}$ was estimated when adding $448.3 \mathrm{~g} \mathrm{~kg}^{-1}$ of elephant grass to the silage, whereas the mold population decreased linearly with increasing proportions of elephant grass in the silage, ranging from 7.24 to
$2.56 \log \mathrm{CFU} \mathrm{g}^{-1}$ for 0 and $100 \%$ elephant grass, respectively (Table 3 ).

There was a linear response of yeast population estimated from 1.09 to $0.02 \log \mathrm{CFU} \mathrm{g^{-1 }}$ in uninoculated silages and from 0.74 to $0.43 \log \mathrm{CFU}$ $\mathrm{g}^{-1}$ in inoculated silages, with proportions of elephant grass from 0 to $100 \%$ in silage, respectively (Table $3)$. Enterobacteria were not detected in the silages.

\section{Fermentation characteristics}

There was a significant effect $(P>0.05)$ of the interaction between proportions of elephant grass and microbial inoculant for $\mathrm{NH}_{3}-\mathrm{TN}(P<0.01)$, BA $(P<0.05)$, and effluent $(P<0.001)$. We detected a simple effect of proportion of elephant grass for pH $(P<0.001)$, LA $(P<0.001)$, and PA $(P<0.05)$. 
There was a simple effect of microbial inoculant for pH $(P<0.001)$ and LA $(P<0.05)$ (Table 2).

Regarding the ammonia nitrogen content $\left(\mathrm{NH}_{3}-\right.$ $\mathrm{TN}$ ) in uninoculated silages, equations of the first, second, and even third degree (which were also tested) were not significant. In contrast, there was a quadratic response for inoculated silage and the maximum $\mathrm{NH}_{3}-\mathrm{TN}$ content estimated from the equations was $118 \mathrm{~g} \mathrm{~kg}^{-1} \mathrm{NH}_{3}-\mathrm{TN}$, which occurred with $14.4 \%$ elephant grass in the silage (Table 4 ).

Table 4

Regression equations for variables fitted as a function of proportions of elephant grass cv. Cameroon (0, 25, 50, 75, and $\mathbf{1 0 0 \%}$ ) of stylo cv. Campo Grande silages, without and with microbial inoculant

\begin{tabular}{lcc}
\hline & Without inoculant & $\mathrm{r}^{2} / \mathrm{R}^{2}$ \\
\hline Yeasts $\left(\mathrm{log} \mathrm{CFU} \mathrm{g}^{-1}\right)$ & $\mathrm{Y}_{\mathrm{S}}=1.08628-0.0106784 \mathrm{X}$ & 0.78 \\
\hline $\mathrm{NH}_{3} / \mathrm{TN}\left(\mathrm{g} \mathrm{kg}^{-1}\right)$ & Mean $=101.8$ & \\
$\mathrm{BA}\left(\mathrm{g} \mathrm{kg}^{-1}\right)$ & $\mathrm{Y}_{\mathrm{S}}=1.70884+0.0446523 \mathrm{X}-0.000447552 \mathrm{X}^{2}$ & 0.54 \\
Effluent $\left(\mathrm{kg} \mathrm{t}^{-1}\right)$ & $\mathrm{Y}_{\mathrm{S}}=5.80802+0.566408 \mathrm{X}$ & 0.58 \\
\hline \multicolumn{3}{c}{ With inoculant } \\
\hline Yeasts $\left(\operatorname{log~CFU~g}^{-1}\right)$ & $\mathrm{Y}_{\mathrm{C}}=0.736614-0.00305892 \mathrm{X}$ & 0.54 \\
\hline $\mathrm{NH}_{3} / \mathrm{TN}\left(\mathrm{g} \mathrm{kg}^{-1}\right)$ & $\mathrm{Y}_{\mathrm{C}}=116.094+0.270231 \mathrm{X}-0.00937565 \mathrm{X}^{2}$ & 0.65 \\
$\mathrm{BA}\left(\mathrm{g} \mathrm{kg}^{-1}\right)$ & $\mathrm{Y}_{\mathrm{C}}=1.62626-0.0160212 \mathrm{X}+0.000165608 \mathrm{X}^{2}$ & 0.57 \\
Effluent $\left(\mathrm{kg} \mathrm{t}^{-1}\right)$ & $\mathrm{Y}_{\mathrm{C}}=6.71285+0.687820 \mathrm{X}$ & 0.77 \\
\hline
\end{tabular}

$\mathrm{BA}$ - butyric acid; $\mathrm{NH}_{3} / \mathrm{TN}$ - ammonia nitrogen related to total $\mathrm{N}$.

The addition of elephant grass in the silages provided a quadratic response for $\mathrm{pH}$ and for LA and PA contents. The maximum $\mathrm{pH}$ of 4.82 was estimated with $38.7 \%$ elephant grass, a minimal LA content of $25.3 \mathrm{~g} \mathrm{~kg}^{-1}$ with $31.2 \%$ elephant grass, and a maximum PA content of $15.3 \mathrm{~g} \mathrm{~kg}^{-1}$ with $50.9 \%$ elephant grass in the mixed silage (Table 3 ).

The butyric acid content exhibited the inverse quadratic response in inoculated and uninoculated silages. In the absence of inoculant, the maximum butyric acid content $\left(2.8 \mathrm{~g} \mathrm{~kg}^{-1}\right)$ was estimated when adding $49.88 \%$ elephant grass. In inoculated silages, $48.37 \%$ elephant grass provided the minimum butyric acid content (1.2 $\left.\mathrm{g} \mathrm{kg}^{-1}\right)$ (Table 4).

Regarding the interaction of proportion of elephant grass and microbial inoculant, the effluent production linearly increased from 5.8 to $62.45 \mathrm{~kg} \mathrm{t}^{-1}$ FW, in uninoculated silages, and from 6.7 to 75.49 $\mathrm{kg} \mathrm{t}^{-1} \mathrm{FW}$, in inoculated silages, for elephant grass proportions from 0 to $100 \%$, respectively (Table 4).

\section{Discussion}

\section{Chemical composition}

The DM content of silage is reduced due to the lower DM content of the elephant grass compared with that of the stylo, when increasing the proportion of elephant grass in mixed silages (Table 3). The DM content of silages was directly related to the forage DM content at the time of treatment (Borreani, Tabacco, Schimidt, Holmes, \& Muck, 2018); thus, this DM reduction was expected due to inherent factor of the elephant grass.

The linear decrease observed for CP content of the silage with increasing proportions of elephant grass is due to the lower CP content of grasses compared with that of legumes. Therefore, the stylo and elephant grass mixed silages exhibited lower CP content than stylo silage. According to Silva et al. (2018), the inclusion of stylo with palisade grass at the proportion of 50:50 in mixed silage is possible 
to increase up to $60 \%$ of CP. However, in our study, silage consisting solely of elephant grass exhibited higher $\mathrm{CP}$ content, which was $86 \mathrm{~g} \mathrm{~kg}^{-1}$, than the results obtained by Garcez, Santos, Machado, Nicolini and Macedo (2018), which was $37 \mathrm{~g} \mathrm{~kg}^{-1}$.

The linear increase for NDF and ADF contents with increasing proportions of elephant grass is related to the higher concentration of structural carbohydrates in the cell wall of grasses. In a similar study, Rigueira et al. (2017) also obtained increased NDF and ADF contents, when studying the increment of stylo levels in silage of marandu grass. The plant respiration or loss of soluble components also may explain the increase of NDF and ADF contents. Consequently, the fiber fraction of silage is as an important factor of the dry matter intake and digestibility in mixed silages in which the stylo added has potential benefit for ruminant production.

The ADIN content in elephant grass silage was half of that obtained in the stylo silage, but the latter had a higher nitrogen content that was not associated with $\operatorname{ADIN}\left(102.7 \mathrm{~g} \mathrm{~kg}^{-1}\right)$, thus favoring a better use of $\mathrm{CP}$ in this silage compared with elephant grass silage, which exhibited $73.7 \mathrm{~g} \mathrm{~kg}^{-1}$ of nitrogen that was not associated with ADIN.

\section{Microorganism population}

Higher proportions of elephant grass in silages reduced LAB population (Table 3). Nevertheless, all the population found are considered adequate in good-quality silages. The use of inoculant was not able to provide benefits to the $\mathrm{LAB}$ population.

Enterobacteria, whose population was detected in fresh samples of stylo and elephant grass was not detected in the silages. The reduction of these microorganisms in silage reflects the combined presence of good ensilability conditions, nutrient and water availability, and efficient nutrient conversion in fermentation products. The rapid elimination of enterobacteria is usually desirable because it limits the fermentation of sugars into acetic acid and the fermentation of amino acids into ammonia (Pahlow, Muck, Driehuis, Elferink, \& Spoeltra, 2003).

The mold population decreased with increasing proportions of elephant grass, regardless of whether the silage had been inoculated; the same finding was observed for the yeast population, although the decrease was sharper in inoculated silages. The linear decrease in mold and yeast populations is likely due to the lower $\mathrm{pH}$ of the silages because the acid and anaerobic environment of silages adversely affect the growth of such microorganisms (Pahlow et al., 2003).

\section{Fermentation characteristics}

Increasing proportions of elephant grass in the silage decreased the $\mathrm{pH}$ as the LA content increased because this acid is stronger than the other organic acids and is the main component responsible for reducing the $\mathrm{pH}$. Thus, the maximum $\mathrm{pH}$ value was observed in all silages where the LA content was the lowest (Table 3). Elephant grass silage obtained a higher LA content and a lower $\mathrm{pH}$ than stylo silage. According to McDonald et al. (1991), the $\mathrm{pH}$ range considered adequate for forage conservation varies from 3.8 to 4.2 , whereas perennial grass and legume silages typically exhibit higher $\mathrm{pH}$ values (Mahanna, 1994).

The ammonia nitrogen content estimated for all silages (Table 4) was below the critical range of 100$150 \mathrm{~g} \mathrm{~kg}^{-1}$, established by Mahanna (1994) for grass and legume silages. Contents of $\mathrm{NH}_{3}-\mathrm{TN}$ higher than $120 \mathrm{~g} \mathrm{~kg}^{-1}$ are associated with protein hydrolysis and indicate poor-quality silage (McDonald et al., 1991). Adding material with higher DM content during the ensilage may aid in producing $\mathrm{NH}_{3}-\mathrm{TN}$ content below the critical level.

According to Mahanna (1994), good-quality silages should have a PA content lower than $10 \mathrm{~g} \mathrm{~kg}^{-1}$ DM. In our study, lower PA content was obtained in stylo silage, whereas higher contents were obtained in elephant grass silage (Table 3). 
Butyric acid contents higher than $1.0 \mathrm{~g} \mathrm{~kg}^{-1}$ indicate undesirable fermentation resulting from the activity of bacteria of the genus Clostridium (Mahanna, 1994). We observed that butyric acid contents in inoculated and uninoculated silages were slightly higher than the maximum content recommended for a good-quality silage. However, without inoculant, silages exhibited higher BA contents than inoculated silages.

When the material was ensiled with a low watersoluble carbohydrate content and a reduced DM content, bacteria of the genus Clostridium grow at the expense of BAL; this process may result in higher BA content and/or more intense proteolysis with consequently increased contents of ammonia nitrogen (Muck, 1996).

The linear increase in effluent production with increasing proportion of elephant grass in the silage is due to the lower DM content of grasses when compared with that of legumes. In the study by Zanine et al. (2010), an effluent production of 40.8 $\mathrm{kg} \mathrm{t}^{-1}$ of fresh weight was observed for elephant grass silage. This value is below than that found for elephant grass silage in our study. However, by mixing stylo and elephant grass we can reduce substantially the effluent production.

\section{Conclusion}

Stylo provides silage with better chemical composition and lower effluent production, although with a higher mold and yeast population than elephant grass. The microbial inoculant does not improve the chemical and fermentative characteristics of silages, except for reducing butyric acid. We recommend uninoculated stylo silage with up to $75 \%$ of elephant grass as an alternative to feed ruminant animals.

\section{Acknowledgments}

Fundação de Amparo à Pesquisa do Estado de Minas Gerais/FAPEMIG; Coordenação de
Aperfeiçoamento de Pessoal de Nível Superior/ CAPES.

\section{References}

Bolsen, K. K., Lin, C., Brent, B. E., Feyerherm, A. M., Urban, J. E., \& Aimutis, W. R. (1992). Effect of silage additives on the microbial succession and fermentation process of alfalfa and corn silages. Journal of Dairy Science, 75(11), 3066-3083. doi: 10.3168/jds.S0022-0302(92)78070-9

Borreani, G., Tabacco, E., Schmidt, R. J., Holmes, B. J., \& Muck, R. E. (2018). Silage review: Factors affecting dry matter and quality losses in silages. Journal of Dairy Science, 101(5), 3952-3979. doi: $10.3168 /$ jds.2017-13837

Detmann, E., Souza, M. A., Valadares, S. C., Fº, Queiroz, A. C., Berchielli, T. T., Saliba, E. O. S.,... Azevedo, J. A. G. (2012). Métodos para análise de alimentosINCT-Ciência Animal. Suprema: Visconde do Rio Branco.

Fernandes, C., Grof, B., Chakraborty, S., \& Verzignassi, J. R. (2005). Estilosantes Campo Grande in Brazil: a tropical forage legume success story. In Proceedings of International Grassland Conference: Offered Papers, Dublin, IRL, 20.

Garcez, B. S., Santos, C. M. D., Machado, F. A., Nicolini, C., \& Macedo, E. D. O. (2018). Ruminal degradation of elephant grass silages added with faveira pods. Acta Scientiarum. Animal Sciences, 40(e39946), 1-7. doi: 10.4025/actascianimsci.v40i1.39946

Jobim, C. C., Nussio, L. G., Reis, R. A., \& Schmidt, P. (2007). Avanços metodológicos na avaliação da qualidade da forragem conservada. Revista Brasileira de Zootecnia, 36(Supl. Esp.), 101-119. doi: 10.1590/S1516-35982007001000013

Kung, L., Jr. (1996). Preparation of silage water extracts for chemical analyses: standard operating procedures. Worrilow: University of Delaware, Ruminat Nutrition Laboratory.

Kung, L., Jr., Shaver, R. D., Grant, R. J., \& Schmidt, R. J. (2018). Silage review: Interpretation of chemical, microbial, and organoleptic components of silages. Journal of Dairy Science, 101(5), 4020-4033. doi: 10.3168/jds.2017-13909

Licitra, G., Hernandez, T. M., \& Van Soest, P. J. (1996). Standardization of procedures for nitrogen fractionation of ruminant feeds. Animal Feed Science and Technology, 57(4), 347-358. doi: 10.1016/03778401(95)00837-3 
Liu, Q., Zhang, J., Shi, S., \& Sun, Q. (2011). The effects of wilting and storage temperatures on the fermentation quality and aerobic stability of stylo silage. Animal Science Journal, 82(4), 549-553. doi: 10.1111/j.1740-0929.2011.00873.x

Mahanna, B. (1994). Proper management assures highquality silage, grains. Feedstuffs, 10(2), 12-56.

Mahanna, B., \& Chase, L. E. (2003). Practical applications and solutions to silage problems. Silage Science and Technology, 42, 855-895. doi: 10.2134/ agronmonogr42.c19

McDonald, P., Henderson, A. R., \& Heron, S. J. E. (1991). The biochemistry of silage (2nd ed.). Marlow: Chalcombe Pub.

Muck, R. E. (1996). Inoculation of silage and its effects on silage quality. In Proceedings of Informational conference with dairy and forage industries (pp. 4351). Madison: US Dairy Forage Res Center.

Oliveira, A. S., Weinberg, Z. G., Ogunade, I. M., Cervantes, A. A. P., Arriola, K. G., Jiang, Y.,... Adesogan, A. T. (2017). Meta-analysis of effects of inoculation with homofermentative and facultative heterofermentative lactic acid bacteria on silage fermentation, aerobic stability, and the performance of dairy cows. Journal of Dairy Science, 100(6), 4587-4603. doi: 10.3168/jds.2016-11815

Pahlow, G., Muck, R. E., Driehuis, F., Elferink, S. J. O., \& Spoelstra, S. F. (2003). Microbiology of ensiling. In D. R. Buxton, R. E. Muck \& J. H. Harrison (Eds.). Silage Science and Technology, 42, 31-93.

Rigueira, J. P., Pereira, O. G., Ribeiro, K. G., Valadares, S. C., Fo., Cezário, A. S., Silva, V. P., \& Agarussi, M. C. (2017). Silage of marandu grass with levels of stylo legume treated or not with microbial inoculant. Journal of Agricultural Science, 9(9), 36-42. doi: 10.5539/jas.v9n9p36
SAEG (2007). Sistema para Análises Estatísticas, Versão 9.1. Viçosa, MG: Fundação Arthur Bernardes.

Silva, J. S. da, Ribeiro, K. G., Pereira, O. G., Mantovani, H. C., Cecon, P. R., Pereira, R. C., \& Silva, J. D. L. (2018). Nutritive value and fermentation quality of palisadegrass and stylo mixed silages. Animal Science Journal, 89(1), 72-78. doi: 10.1111/ asj. 12854

Silva, T. C. da, Pereira, O. G., Agarussi, M. C. N., Silva, V. P. da, Silva, L. D. da, Cardoso, L. L.,... Valadares, S. C., F $F^{o}$. (2015). Stylosanthes cv. Campo Grande silage with or without concentrate in sheep diets: nutritional value and ruminal fermentation. Small Ruminant Research, 12, 34-39. doi: 10.1016/j. smallrumres.2015.03.011

Souza, W. F., Pereira, O. G., Ribeiro, K. G., Santos, S. A., \& Valadares, S. C., F ${ }^{o}$. (2014). Intake, digestibility, nitrogen efficiency, and animal performance of growing and finishing beef cattle fed warm-season legume (Stylosanthes capitata plus Stylosanthes macrocephala) silage replacing corn silage. Journal of Animal Science, 92(9), 4099-4107. doi: 10.2527/ jas.2013-7480

Yahaya, M. S., Goto, M., Yimiti, W., Gamo, Y., Kim, W., Karita, S.,... Ogawa, S. (2004). Epiphytic microbiota on tropical Tinaroo legume (Neonotonia wightii) as revealed by denaturing gradient gel electrophoresis (DGGE) and scanning electron microscopy (SEM) and their effects on silage fermentation and ruminal degradability. Journal of Animal and Veterinary Advances, 3(6), 340-347. doi: javaa.2004.340.347

Zanine, A. D. M., Santos, E. M., Dórea, J. R. R., Dantas, P. A. D. S., Silva, T. C. D., \& Pereira, O. G. (2010). Evaluation of elephant grass silage with the addition of cassava scrapings. Revista Brasileira de Zootecnia, 39(12), 2611-2616. doi: 10.1590/S151635982010001200008 